\title{
Bálint Gábor, Pröhle Vilmos és a japán-magyar nyelvhasonlítás története
}

1. 150 év telt el azóta, hogy 1844. március 13-án megszületett Bálint Gábor (1844-1913) a Háromszék megyei Szentkatolnán (Catalina, ma Románia), az akkori Magyarország keleti szélén. A székely tudós, miután több mint egy évtizedig hányódott Európában és Ázsiában, visszatért hazájába, és a kolozsvári Királyi Ferenc József Tudományegyetemen az urál-altaji összehasonlitó nyelvészet tanáraként oktatott az 1893/94. tanév 2. felétöl az 1911/12. tanévig. 1977-ben Ligeti Lajos a Gombocz Zoltán mint turkológus címü cikkében a következöket írta: „Bálintot az altaji nyelvek érdekelték csupán, használható, jó anyagot közölt törökböl (kazáni tatárból) és mongolból (burjátból). Összehasonlító nyelvészetből csak meghökkentően dilettáns müveket produkált (magyar-mongol, magyar-dravida, magyar-kabard nyelvrokonság). Az ő helyére került 1914-ben Gombocz Zoltán, megjelenése a katedrán alig mérhető színvonal-emelkedést jelentett."' György Lajos irodalomtörténész pedig, aki 50 évvel ezelött elöadást tartott Bálint életéröl és munkásságáról születésének 100. évfordulója alkalmából, arról szólt, hogy „A méltánytalanság ott érte Bálint Gábort, amikor tévedései mögött nem látták és nem is becsülték meg azt a pozitiv értékanyagot, amelyet Oroszországban és Azsiában, nagy tudással és kifogástalan módszerrel, a tudomány számára hozzáférhetövé tett."² Munkái egyes részeinek értékét mutatja, hogy az utóbbi évtizedekben török, mongol és mandzsu vonatkozású müveit utánnyomásból vagy kéziratából megjelentetik. ${ }^{3}$

Az alábbiakban elöször Bálintnak egy terjedelmes dolgozatáról szeretnék szólni, amely a japán-magyár nýelvhasonlitás történetének szempontjából érdekes, és tudtommal az ismeretlenség homályában hever. Ismeretes, hogy a székely nyelvész tagja lett Széchenyi Béla keletázsiai expedíciójának, amely 1877 decemberében indult Triesztböl, de egyedül ö indult vissza hamarabb Európába, 1878 tavaszán. György Lajos azt állitja, hogy Bálint Sanghajból „Japánba is átnézett". Maga Bálint azonban a "Minó fajuiak a japánok (nipponiak)? címü, "1894-ben megjelent cikkében' nem szól japáni tartózkodásáról, amikor a japánokkal való első (1872-ben Szentpétervárott) és második (1878-ban Sanghajban) találkozásảról beszẻl, és 1878-ban még a „legkisebb gondot sem” forditotta a japán nyelvre. Később pedig ez a nyelv nagyon foglalkoztathatta öt, és a fent említett 1894-es cikkében azt írja, hogy „Több mint 800 (nyolcszáz) magyar alapszónak társait tudom kimutatni a nipponi nyelvben”. Ezen szóegyeztetései néhány év múlva valóban napvilágot láttak, de - úgy tünik - nem szerzett tudomást róluk a magyar tudomány világa.

Ezzel kapcsolatban említést érdemel az, hogy tudósunk a kolozsvári egyetemen, ahol föleg altaji nyelvekröl adott elö, az egyetemi tanrend szerint az 1895/96. tanévtöl nyolc féléven keresztül tanitott japán nyelvet is heti két órában. ${ }^{6} \mathrm{Az} 1895 / 96$. tanév 1 . fẻlévére vonatkozó tanrend a következö óráit hirdeti: Kabard nyelvtan. Heti egy óra. | Nipponi nyelvtan. Heti 2 óra. | Török-tatár nyelvtan és szövegolvasás. Heti 2 óra. | Ta hio (A nagy tan) mandzsu nyel-

${ }^{1}$ MNy. LXXIII. 396.

${ }^{2}$ György Lajos: Bálint Gábor cmlekczete. Egy kolozsvári egyetemì tanảr oroszorszảgì és belsỏảzsià nyelvtanulmányai. Kolozsvár 1945. 29; 1. még Zágoni Jenö: 130 éve született Szentkatolnai Bálint Gábor. Aluta VI/VII (1974/75), 373-89.

${ }_{3}^{3}$ L.: Louis J. Nagy: Acta Orientalia IX (1959), 311-27; G. Kam: Narody Azii i Afriki 1962/1, 161-4; Bálint Gábor keleti levelei. Bevezetövel újm közreadja Kara György. Bp., 1973.; Wolgatatarische Dialektstudien. Textkritische Neuausgabe der Originalsammlung von G. Bálint 1875-1876. Hrsg. von A. Berta. Bp., 1988.

4. $m .17$

5 Erdélyi Múzeun XI, 584-5.

'György (i. m. 22.) csak négy félévröl beszél. 
ven. Heti 1 óra. ${ }^{7}$ Tekintettel arra, hogy annak idején az uráli és az altaji nyelveket általában egy családba tartozónak vélték, és vitatkoztak azon, hogy a japán nyelv beleillik-e e nyelvcsaládba, az urál-altaji nyelvészeten belül a japán nyelvet oktatni nem elképzèlhetetlen, bár elég szokatlan. Mindenesetre, azt mondhatjuk, hogy Bálint úttörő szerepet játszott a japán nyelv oktatásában a magyar egyetemeken. Nem tudjuk, hogy mi késztette ổt arra, hogy 1899-től abbahagyja e nyelv tanitását.

Ezen időszak előttre, 1897-re esik Bálint „Tamul (dravida) tanulmányok. Első rész: tamul nyelvtan (latinos átírással), tekintettel a többi tizenegy társnyelvre és a magyarra. Második rész: magyar-tamur gyöknyomozó szótár, tekintettel a középturánság főbb nyelveire"8 címü munkájának megjelenése. Megjegyzendő azonban, hogy Bálint e müve, amelynek magját „a hontalanság 11 éve alatt” készítette, már sokkal korábban kész volt, hiszen a „Bevezetés” végén a következő áll: „Szent-Katolnán, 1891. tavaszelő 7-dikén”. (Ez a dátum nem egyezik meg György állitásával, miszerint Bálint közel másfél évtizedes európai és ázsiai hányódása után, 1892-ben hazaérkezett. ${ }^{9}$ A Magyar Néprajzi Társaság 1891. február 28-i ülésén.pedig előterjesztették Bálint egy írását: Ethnographia II [1891], 138. Bálint valószinüleg 1879-től 1890- ig tartózkodott külföldön.) Ligeti Lajos ezt a müvet sajnála tos eltévelyedése terjedelmes megnyilvánulásának nevezi, miután megjegyzi, hogy Bálint „a mongol után a dravida nyelveket tette meg a magyar nyelv rokonául és egy meglehetősen zavaros turáni nyelvcsaládba gyömöszölte a tamult, a magyart a mongollal együtt. ${ }^{10} \mathrm{Kara}$ György, aki 1973-ban újra kiadta Bálint néhány közleményét utánnyomásban, bevezetésében a következőket íja: tudósunk „Bombayban ismerkedett meg a régi és nagy irodalmú tamil nyelvvel, fedezte fel, menthetetlenül, az új rokonságot (amely, a mi legjobb tudomásunk szerint, nem több bizonyos szerkezeti, tipológiai és nem genetikai rokonságnál, mely pl. a bolíviai kecsua nyelvröl is állitható)”.' Ligeti és Kara, akik csak a fent emlitett magyar nyelvü kiadásra hivatkoznak, nem tesznek emlitést Bálint japán-magyar nyelvhasonlitásáról. Az ember azt gondolhatja, hogy az egy évvel később Bécsben megjelent német nyelvű kiadás ${ }^{12}$ azonos tartalmú a magyaréval, de a két kiadás összehasonlitásából kiderül, hogy Bálint nemcsak ảtdolgozta a magyar kiadást, hanem müve végéhez hozzácsatolta az ,Anzug des Japanischen Wörterbuches. Nach J. C. Hepburn's japanischen Wörterbuche (A Japanese-English and English-Japanese Dictionary by J. C. Hepbum etc. 4. Ed. Tokyo, 1888) címú részt is, amely tulajdonkẻppen japán-magyar szóegyeztetésekből áll a 380. laptól a 429-ig terjedően (negyedrét alakban). A "Bevezetés" is teljesen más, és helyére az "Einleitende Bemerkungen (5-37) kerül, amely a "turáni" nyelvek (tamil, japán, koreai, magyar, török-tatár, mongol, finn, mandzsu, szamojéd stb.) rövidre fogott nyelvtaui összehasonlítása. Itt a műve végén talảlható „Anzug”-ról Bálint a következöképpen nyilatkozik: „Meiner Ansicht nach ist es ein zweites Hauptdokument des Turanentums, die Geschwister von 800 und etlichen magyarischen Grundwörtern dort zu sehen, was vielleicht genug ist, uin die, welche die Verwandschaft leugnen, zum Schweigen zu bringen." ${ }^{13} \mathrm{Az}$ átdolgozást és a kiegészítést tudósunk bizonyára a magyar változat 1891 . évi elkészitése után hajtotla végre.

Bizonyos, hogy Bálintnak a magyar-tamil rokonságról szóló elmélete, amelyről már korábban is hangot adott ${ }^{14}$ visszatetszést keltett a magyar szakemberek körẻben, ỉgy talán már egy

\footnotetext{
${ }^{7}$ A Kolozsvári Magyar Királyi Ferencz-József-Tudomány-egyetem almanachja és ianrendje. Az MDCCCXCVIVII-iki tanév 1. felére. Kolozsvár. 1898. Az óríkkal kapcsolatban a továbbiakban is a kolozsvári egyeten tanrendjeinek adataira támaszkodon.

In: Gróf Széchenji Bela keletázsiai litjänak tudományos eredményci. II. Bp., 1897. 1-341.

9.m. 21 .

${ }^{10}$ NyK. XLIX (1935), 190.

il $1 . m .7$

${ }^{12}$ Tamulische (Dravidische) Studien in zwei Teilen. I. Grammatikalischer Teil. Il. Lexikalischer Teil. In: Wissenschaftliche Ergebnisse der Reise des Grafen Bela Szechenyi in Ostasien 1877-1880. Zweiter Band. 1-432. Wien, 1898.

${ }^{1}$ l.m. 36.

${ }^{14}$ ErdMuz. V (1 888.), 33-55, 215-36.
} 
csepp figyelmet sem forditottak a német kiadásra. Heinrich Winkler wroclawi (breslaui) tudós pedig, aki az ún. urál-altaji nyelvek közé sorolta a japánt is, szentelt egy recenziót Bálint német nyelvủ munkájának. Hosszasan ecsetelve elvetette Bálint véleményét a magyar-tamil nyelvrokonságról. ${ }^{15}$ Winkler azonban, aki múveiben ${ }^{16}$ különben sem vállalkozott akkor még az urál-altaji nyelvek szókincsének a japánéval való egyeztetésére, recenziójában egy szót sem szól Bálintnak a félszáz oldalt kitevő japán-magyar szóegyeztetéseiröl.

2. Közel két évtizeddel Bálint szóban forgó munkája után a Keleti Szemlében lát napvilágot az ő nézetéhez bizonyos mértékben hasonló tanulmány Prölıle Vilmos (1871-1946) tollából. (Pröhlét elsősorban turkológusként tartják számon.) § a Studien zur Vergleichung des Japanischen mit den uralischen und altaischen Sprachen ${ }^{17}$ cimü irásában, amelyben érdekes módon alig szentel figyelmet az altaji nyelveknek, az uráli nyelvekkel rokonitja a japánt. Tanulmányában, amelyben hangmegfeleléseket törekszik megállapitani, 10 morfológiai párhuzam mellett 90 japán-uráli szóegyeztetés is található. Ha e 90-böl megfigyeljük az elsô 15 japán szót, közülük 9 szerepel Bálint „Anzug”-jában is cimszóként, s ebből Pröhle 5-nek (hineru, hirumu, ho, fukumu, furu) nagyjából ugyanazt a magyar megfelelöt javasolja, mint Bálint, 2 szóegyeztetése pedig (he, hito) nem esik távol Bálintétól.

Pröhle tanulmányának elején emlitést tesz az ez irányú korábbi kutatásokról, J. Grunzelről, A. Bollerröl és H. Winklerröl, de Bálintról szó sincs. A japán-uráli szóegyeztetéseiben Pröhle többször hivatkozik Boller munkájára ${ }^{18}$, mint például a fent emlitett 9 japán szó közül kettőnél. Pröhle vajon nem ismerte Bálint dolgozatát? Vagy vajon nem akart hivatkozni a székely tudósra, aki a magyart és a japánt a tamillal rokonitotta, vagy pedig müve elhallgatására az akkori magyar nyelvtudomány világában uralkodó légkör kẻsztette, amely ignorálta Bálint összehasonlitó nyelvészeti munkásságát?

Pröhle egy cikkében 1899-re visszaemlékezve azt irja, hogy akkor már „kotyogni” tudott japánul. "> 1908-tól, amikor még a nyiregyházi evangélikus fơgimnázium tanára volt, a kolozsvári egyetemen is.tanitott magántanárként, tehát Bálint kollégája lett néhány évre, söt az 1910/11. tanévtől - az 1911/12. tanév 1. félévét kivéve - az 1912/13. tanév 1. félévéig. japánul is tanitott. İzelitőül vessünk pillantást Bálint és Pröhle óráira az 1910/11. tanév 1 . félévében: Bálint Gábor: Kabard nyelvtan, tekintettel a fỏbb turáni nyelvekre. Heti 2 óra. Török nyelvtan, tekintettel a mongol és mandzsu nyelvekre. | Heti 2 óra. | Mandzsu nyelvtan, tekintettel a mongol és török nyelvekre. Heti 1 óra. - Pröhle Vilmos: Török-tatảr-ugor nyelvhasonlitás. Heti 1 óra. | Oszmanli-török nyelvtan. Heti 1 óra. | Bevezetés a japáni nyelvbe. Heti 1 óra. - Ha a két tudós találkozott, köztük vajon egyszer sem esett szó a japán nyelv hovatartozásának kérdéseiröl, és Bálint vajon nem is tett emlitést sajảt munkảjárỏl?

3. Amint az alább közlendő levélből is kitünik, amelyet Pröhle a Keleti Szemle egyik szerkesztőjének, Munkácsi Bernátnak küldött ${ }^{20}$ tanulmánya az 1917-es megjẹenésénél már évekkel előbb kész állapotban volt.

„Nagyságos Uram!

Mellékelve bátorkodom most készülỏ munkámnak, mely a finn-ugor és japảni nyelvrokonságról szól, egy részét a Keleti Szemle számára elküldeni. A folytatását talán már a jövő hétfön postára adhatom.

A multkor küldött füzetkéröl, valamint két a japáni nyelvészet körébe vágó ủjabb könyvröl rövidesen küldök ismertetést.

${ }^{15}$ Literatisches Centralblatt 1899. No, 17.593-6.

$16 \mathrm{Pl}$. Uralaltaische Völker und Sprachen. Berlin 1884.

${ }_{17}^{17}$ KelSz. XVII (1916/17) 147-83.

18 Nachweis, dass das Japanische zum ural-altaischen Stamme gehört. In: Sitzungsberichte der philos.-histor. Classe der kais. A kademie der Wissenschaften [Wien] XXXIII (1857), 393-481.

${ }_{19}^{19}$ Napkeletröl. Bp., 1922. 39.

${ }^{20}$ MTA Kézirattár Ms $10.283 /$ t. 
Mindezeket a dolgokat régen rendbehoztam volna, de mostanában igazán oly sok dolgom volt, hogy alig gyöztem.

Ujságul azt irhatom, hogy Kolozsvárt Zolnai és társai megfelelő taktikával elérték, hogy a bölcsészeti kar 8 tagja 6 ellenében Gombocz Zoltán meghivása mellett szavazott. Hogy milyen szépen ment ez az ügy, azt nem részletezem, csak jellemző az illető társaság felfogására: Gomboczék köre engem még „nyelvésznek” sem hajlandó elismerni, Gombocz ur ellenben még olyan tanszék betöltésére is alkalmas, amelyhez nincsenek meg a megfelelö nyelvi és irodalmi ismeretei!

Egyébiránt a meghivás ellen, miként értesültem, megtörtént a tiltakozás.

Magamat Nagyságodnak szives jóakaratába ajánlva maradok mély tisztelettel kész szolgája Nyiregyháza, 1913. III. 4.

Dr Pröhle Vilmos"

Munkácsi erre azonnal visszaküldte a kéziratot, s ez nyilván elkeseritette Pröhlét (1913. III. 9). ${ }^{21}$ Valószinü, hogy Pröhle ezután megfogadva Munkácsi tanácsait és javaslatait, átdolgozta tanulmányát (1913. V. 19.). Ily módon már 1913 nyarán (1913. VI. 30.) elkészült vele, amelyben már felhasználhatta az ez irányú kutatások úttöröjének, Bollernek fent emlitett múvét is (1913. VI. 6.). Azonban úgy tünik, hogy Munkácsi még kifogásolta egyebek mellett Pröhle japán-uráli szóegyeztetéseinek bizonyos részeit (1913. VIII. 24.), és dolgozata sem 1913-ban, sem pedig 1914-ben nem került közlésre. 1915-ben Pröhle érdeklödik Munkácsitól arról, hogy mi lesz a „már régen heverö japáni” tanulmányával (1915. IV. 19.). Ezzel kapcsolatban Munkácsi többek között azt tanácsolhatta Pröhlének, hogy rövidítse le tanulmányát. „Ami japáni tanulmányommal tervezett rövidítéseit illeti - írja Pröhle Munkácsinak - , azokra nézve az a véleményem, hogy ha Gombocz vagy Zolnai irta volna ezt a dolgozatot, akkor nem próbálnák közlés elött amputációnak alávetni. De nálunk úgy látom, nem az a lényeges, hogy mit, milyen alapon és hogyan ir meg az ember, hanem az, hogy ki a szerzó" (1915. IV. 19.). Ránk maradt egy piszkozata annak a levélnek, amelyet Munkácsi Pröhlének küldhetett 1917 júliusában a csehországi hadifogolytáborból, ${ }^{22}$ ahol az oszét foglyok nyelvét tanulmányozta. ${ }^{23}$ Eszerint: „Evvel a cikkel én a legjobb indulattal s lelkiismeretességgel veszỏdtem. Mindent meghagyta m benne, ami lényegileg hozzátartozott s ami valamennyire elfogadhatónak tetszett (jobban mondva nem viselte magán már elsỏ tekintetre a lehetetlenség bélyegét). Avval a föltétellel is vállaltam kiadását, ha szabad kezet hagy a szerkesztésben, mind ezért igen sajnálom a velem szemben tanúsitott méltánytalan eljảrását." Pröhle végül kẻnytelen volt elfogadni cikke leröviditését, és a korrektúra elvégzésekor közli Munkácsival, hogy nem egy szóhasonlitását nehéz szivvel, de nélkülözte (1917. VIII. 8.). Így tanulmánya „horribilis kihagyások"-tól szenvedve, ahogy Pröhle nevezi (1917. IX. 5.), végre napvilágot lát 1917-ben.

Pröhle ugyanabban az évben munkája II. részét átdolgozza (19̄17. X. 20.; 1917. XI. 10.). 1918. május 17-i levelében pedig, amely az MTA Könyvtára Kézirattárában ránk maradt utolsó levele Munkácsihoz, a következóket olvassuk: „Ha a Studien zur stb. II. része még nem volna sajtó alatt, úgy szivesen elküldöm annak egy másik példányát, amely pozsonyi pályázatom mellékletei között szerepelt. Ez a kézirat azonos ugyan a másikkal, de mivel jóformán kalligrafice van írva, a szedőre nézve sokkal kellemesebb lehet." Azonban a II. rész soha nem jelent meg a Keleti Szemlében, amely az I. világháború után ritkábban, az utolsó, XXI. kötete (1928/32) pedig 1932-ben került kiadásra. Ez a dolgozat önálló kiadványként csak 1943-ban látott napvilágot Grundriss einer vergleichenden Syntax der uralaltaischen Sprachen mit besonderer Berücksichtung der Japanischen Sprache cimmel Budapesten. Itt Pröhle az elöszó-

\footnotetext{
${ }^{21}$ Az ilyen dátum zárójelben a továbbiakban is azt jelzi, hogy forrásul használjuk Pröhlẻnek Munkảcsihoz az adott idöpontban intézett - az MTA Könyvtára Kézirattárában Ms $10.283 /$ jelzés alatt megörzött - leveleit.

${ }^{2}$ MTA Kézirattár Ms 10. 283/t.

${ }^{23}$ KelSz. XVIII (1918/19) 146.
} 
ban arról szól, hogy bár a dolgozat már 1917-ben készen volt, az I. világháború tragikus következményei lehetetlenné tették a közzétételét, de a megjelenés késésében az is közrejảtszhatott, hogy Munkácsi nem küldte azonnal nyomdába, hanem a Keleti Szemle szerkesztőségében hevert huzamos ideig. Érdekes jelenség az, hogy ezzel szemben Décsy Gyula meleg és további kutatásokra biztató előszavával adta ki 1978-ban Pröhle kéziratban maradt munkảját Vergleichende Syntax der ural-altaischen (turanischen) Sparchen (Autograph-Ausgabe, Wiesbaden) címmel, amely az 1943-as könyvecskéjének bövitett változata.

4. A fentebb teljes terjedelemben közölt levélben, amelyet Pröhle intézett Munkácsihoz 1913. március 4-én, a kolozsvári egyetem urál-altaji philológiai szemináriuma vezető tanári állásának betöltésével kapcsolatban esik szó Gombocz Zoltánról és Zolnai Gyuláról. Pröhle, aki Bálint nyugállományba vonulása után is tanított az 1912/13. és 1913/14. tanévben, bizonyára abban reménykedett, hogy Bálint helyére őt nevezik ki. A dolog azonban nem igy alakult, és Budapeströl a Pröhlénél fiatalabb Gomboczot hivták meg, s ez igen elkeserithette öt. „Panaszkodni nem szeretek, de annyit mondhatok - irja Pröhle Munkácsinak - , hogy amilyen eszközökkel például Goníbocz és barátai ellenem dolgoztak és dolgoznak s rólam mint egyszerű nyelvmesterről és belletristáról beszélnek, az bizony már nagyon elkeserit.” „... a kolozsvári kérdés Gomboczék illetéktelen közbelépése miatt úgy ảll, ahogyan áll" (1913. III. 13.). Ez a dolog másik oldalára vethet fényt. Gombocz nem az 1913/14., hanem az 1914/15. tanévtől kezdett ott tanitani, Pröhle azonban már csak az 1914/15. és 1915/16. tanéveknek az I. felében müködik, s azután végleg abbahagyja a kolozsvári egyetemen való tanárkodást. $\mathrm{Az}$ 1916/17. tanévtől Nyíregyházáról Debrecenbe költözve a debreceni egyetemen magántanárként, az 1918/19. tanévtől pedig c. ny. rk. tanárként oktat turkológiát. ${ }^{24}$

Mindenesetre emlitést érdemel az a különös helyzet, amely az I. világháború elött a kolozsvári egyetem urál-altaji philológiai szemináriumát jellemezte. Tudniillik itt megelőzve a budapesti egyetemet már közel egy évszảzaddal ezelött megkezdődött a japán nyelv oktatása, és kisebb-nagyobb megszakításokkal folytatódott az urál-altaji nyelvészet tárgykörén belül. Ha meggyőző bizonyítást nyert volna az a nézet, miszerint a japán nyelv az altaji vagy az uráli nyelvcsaládhoz tartozik, akkor a japanológia az azóta történt viharos események ellenére szépen felvirágzott volna Magyarországon, amely az uralisztika és altajisztika egyik központja a világon. Visszatekintve azt mondhatjuk, hogy a korai magyarországi japanológia, amely a magyar nyelvhasonlításból indul ki, eleve kudarcra volt ítélve.

5. Koizumi Tamotsu, aki egyébként az uralisztika ritkaságszámba menỏ japán mủvelöje, összefoglalta a különbözö hipotéziseket a japán nyelv kialakulásáról és hovatartozásáról, ezeket két (I. és II.) csoportra osztva. I. A japán nyelv azonos eredetủ X nyelvvel. Ezen típuson belül többek között a) a ryükyü (bizonyítást nyert), b) a koreai, c) a mongol, d) az uráli és altaji, e) a tibeto-burmai és fi) a tamil jöttek szóba. II. A japán nyelv $\mathrm{X}$ nyelvre $\mathrm{Y}$ nyelv rárakódásával alakult ki. E típus két altípusra tagolódik: 1. két nyelv egymásra rakodásával, 2. több mint három nyelv egymásra rakódásával alakult ki a japán nyelv. Ezeken a hipotéziseken belül is vannak változatok. Például az 1 . még az alảbbi nézetekre oszlik: a) egy déli (ausztronéziai) nyelvre és északi (mandzsu-tunguz) nyelv, b) egy északi nyelvre egy déli nyelv, c) egy déli nyelvre egy nyugati (uráli) nyelv rakódott rá. Maga Koizumi úgy véli, hogy a japán nyelv a ryükyü testvémyelvvel együtt egy nyelvcsaládnak tekinthető. ${ }^{25}$

\footnotetext{
${ }^{24}$ Pröhie 1923-tól 1942-ig mint a kelet-ázsiai nyelvek tanára japánul is tanít a budapesti egyetemen, de ez alatt az idöszak alatt - bár megjelenteti $A$ japáni nemzeti irodalom kis tükre (Bp. 1937) címü úttörö könyvet - nem tesz közzé egyetlenegy tudományosnak nevezhetô japán vonatkozảsủ imást sem, söt egèsz èletẻben az emlitett két német nyelvün kivül ìs csak egy ilyen irísról van tudomásunk, mégpedig a kolozsvári müködése idejéböl: Ethn. XXII (19II).

${ }^{25}$ Koizumi Tamotsu: Nihongo no keitô. In: Kindaichì H. - Hayashi O. - Shibata T. (szerk.): Nihongo hyakka dai-jiten. Tokió 1988. 8-18; l. még Tokunaga Yasumoto: A japán nyelv hovatartozásának kérdéséröl. MTA I. OK. XXIII (1966), 4I-7.
} 
Ha Bálint véleményét beillesztenénk a fenti csoportositásba, bizonyos értelemben az I. d)hez is és az I. f)-hez is tartozna. Megjegyzem azt, hogy Bálint egy amerikai misszionárius, J. C. Hepburn szótárának 4. kiadását használhatta, amelyről elismeréssel szól. Hepburn (18151911) az első kiadást, amely 1867-ben jelent meg és a világ elsỏ komoly japản-angol szótára lett, átdolgozta és kiegészítette, és az 1866. évi 3. kiadás, amelyben már alkalmazta az ún. Hebon (Hepburn) szisztémát, a most is általánosan használatos átírási módszert, az első kiadás címszavainak kb. 1,7-szeresét, 35518 címszót tartalmazott a japán-angol részben. ${ }^{26}$ Bálint szóegyeztetéseiben több mint másfél ezer japán szót választott ki Hepburn szótárảból, betürendbe szedte, és ezeket hasonlította össze magyar és némely esetben más „turáni” szavakkal. Bálint dolgozata, bár föleg a japán-magyar szókészlet felületes hasonlósảgán alapul, bizonyára felkeltette volna legalább azok érdeklődését, akik a japán nyelv hovatartozásának kérdését uráli, illetve magyar irányból próbálják megközelíteni. Ki gondolná, hogy a Tamulische Studien címet viselő terjedelmes müben félszáz oldalas japản-magyar szóegyeztetések találhatók. Nem csoda, hogy nemcsak a japán nyelvhasonlítás történetéről beszámolók számára ${ }^{27}$ maradt ismeretlen, hanem a magyar nyelvhasonlítás történetéről értekezők számára is. Pusztay János a magyar nyelvhasonlítás történetéről szóló könyvében a magyar-japán nyelvhasonlítással kapcsolatba röviden bemutatja Pröhle 1917-es írásảt, mondván, hogy szóegyeztetéseinek többsége nem állja ki a nyelvészeti kritikảt; Bálintot azonban meg sem említi, hanem Pap Ferencnek az ennél jelentéktelenebb „A japán-magyar nyelvrokonság "28 címü könyvecskéjéröl szól „A nyelvhasonlitás a politika uszályában” fejezetben. ${ }^{29}$ Kazár Lajos a "Japanese-Uralic language comparison; locating Japanese origins with the help of Samoyed, Finnish, Hungarian, etc.: An atempt" (Hamburg 1980) cimủ könyvének bevezetésében a japán-uráli nyelvhasonlítás történetéről röviden írva elismeréssel szól Pröhle munkáiról, utal Pap fent említett dolgozatára is, de Bálint nevét ö sem említi. A Bibliographie der uralischen Sprachwissenschaft $1830-1970^{30}$ címü könyv magyar nyelvhasonlításról szóló fejezetében pedig szerepel Bálint szóban forgó munkája, melynek cime a következỏkkel van kiegészítve: „Auszug aus J. Hepburn`s Japanischen Wb. (mit ung. Etym.)”.

Izui Hisanosuke, aki Koizumi fenti csoportosítása szerint a II. 1. c típusú elméletet képviselte, 1952-ben közzétette A japán nyelv hovatartozása - a japán nyelv és a finnugor nyelvek c. írását. ${ }^{31}$ Izui, aki kevés nyelvi anyagra támaszkodott, kapcsolatba hozta a japán yuki (hó) szót a finn jaa és a magyar jég szavakkal. Pröhle 1917-es tanulmányában ezt a szót nem említi meg, Bálint munkájában viszont a következő áll: „(snow. Man. juhe, ice. Hung. jèg, jég id. Mong. jikegő, kalt. Vog. yang. Ostj. yenk. Fin. jää. Zür. yi, yi id.)”. Első pillantásra ez a japán-magyar szóegyeztetés nem tủnik annyira erỏltetettnek, és valószínủ, hogy ha Pröhle valóban figyelembe vette volna Bálint mủvét, ötletét elfogadva minden bizonnyal fel is vette volna ezt a japán szót a japán $y(=j)$ és az uráli $j$ hangmegfelelést mutató szavak között. Winkler is ezt a magyar-japán szómegfelelést javasolja a Der Uralaltaische Sprachstamm, das Finnische und das Japanische (BerlinT 1909. 268) címủ könyvében, amelynek felhasználását Munkácsi valószínüleg tanácsolta Prönlének (1917. VIII. 8.), aki azonban csak a könyv címét említi meg írása elején. Később Pröhle fentebb idézett japán irodalomról szóló könyvẻben már a yuki szót a magyar jég japán megfelelöjének tartja. ${ }^{32}$ Megjegyzendö, hogy a japán-uráli nyelvhasonlitás jelenkori képviselője, Kazár is ugyanúgy jár el, mint Bálint, bár nem tér kỉ az

${ }^{26}$ Suginum Tsomu: Seiyojin no nilhogo hakken. Tokió 1989. 254-63.

27 L.: Sasaki Takashi: Nihongo no keitöton-s/u. In: Iwanami köza, Nihongo XII. kötet. Tokió 1978. 301-46; Sakiyama Osamu: Nihongo keitoron kankei chosaku ronbun mokuroku. In: Uö. [szerk.]: Nihongo no keisei. Tokió 1990. 407-41.

28 Bp. 1944.

${ }^{29}$ Pusztai János: Az „ ugor-török " háború után. Bp. 1977. 24-30; I. még Zsirai Miklós: Östörténeti csodabogarak: MgÖstört. 277-8.

${ }^{0}$ Hrsg. v. W. Schlachter - G. Ganschow. Band I. München 1974-76. 165.

${ }^{31}$ Kokugokaku 1952.9. s2. 14-22.

32 I. m. 16. 
altaji (mongol) szavakra. Kazár, akinek rendelkezésére állnak a modern nyelvtudomány különböző eszközei, könyvének nagyobb részében betürendben összesen 595 japán szónak végzi el az uráli szavakkal való „etimológiai hasonlításai“-t. ${ }^{33}$ Természetesen vannak olyan japán-magyar szóegyeztetései, amelyeket Bálint már javasolt, de van olyan is, mint a japán hire (uszony) és a magyar fül egyeztetése, amelyeket Bálint nem említ, Pröhle pedig kihagyni kényszerült Munkácsi kifogásolására (1913. VIII. 24.).

Izelítőül idézzünk még két japán szócikket Bálint nűvébỏl: ase (sweat, perspiration: asebo, ase-mo, prickly heat. Hu. izz-ó hö, izz-, izz-ad-, in Schweiss kommen. Vog. is-il-warm werden. T.- tart. issī, warm. Zür. özyi- to burn. Mord. ezze-to warm cf. atsu). - ha (ba tooth: Tam. 1. pal, palla, tooth; 2. pûu, püv = Fin. pii, dens occae, pectins. C̈er. püy, dens. Vog. pänk Zahn. Hu. fog id.). Az elöbbi japán szót Pröhle nem emliti, Kazár viszont Bálinthoz hasonlóan vélekedik; ami a másodikat illeti, a három tudós véleménye között nincs nagy különbség, ha figyelmen kivül hagyjuk a tamilt.

A ha példa különösen érdekes, mégpedig a japán-tamil nyelvhasonlítás történetének szempontjából. A japán-tamil nyelvhasonlítási elmélet az 1970-es években lépett színre Japánban, és nagy vihart kavart a napi sajtóban is. Azért is érdekes, mert Bálint japán-magyar szóegyeztetéseiben, saját elméletéhez hiven, megfelelőnek vélt tamil szót is gyakran tüntet fel, és a japán-tamil nyelvhasonlítás jelenkori képviselői is éppen a ha szót hozzák kapcsolatba a tamil pal szóval. ${ }^{34}$

A nyelvtudomány szakterületétől távol lévén, nem vagyok képes ítélkezni arról, hogy Bálint müve a korabeli nyelvtudomány igényeinek milyen fokon felelt meg. Azok a nyelvészek, akik a japán nyelv hovatartozásának rejtélyes kérdéseire az uráli nyelvekkel, többek között a magyarral vagy esetleg a tamillal való összehasonlitás alapján törekszenek fényt deriteni, vajon azt gondolják, hogy Bálint közel 100 évvel ezelőtt készült dolgozatát egyáltalán nem érdemes figyelembe venni és megemliteni sem? Bálint müvét ma már - akár értéktelen, akár nem - nem tartom teljesen mellőzendőnek, hiszen legalábbis annyi bizonyos, hogy jó szórakozást kinál a japánok és a magyarok számára, akik a magyart vagy a japánt idegen nyelvként tanulják.

Mindenesetre tény, hogy napjainkban is napvilágot látnak olyan tanulmảnyok, amelyek a dravida-altaji nyelvhasonlításról vagy nyelvi kapcsolatokról szólnak; a japán-tamil nyelvhasonlításról élénk vita folyik, melynek mérlege ellenzỏinek javảra billen. $\mathrm{A}$ japán-uráli (ill. magyar) nyelvhasonlítás sem került le teljesen a napirendröl. ${ }^{35} \mathrm{Az}$ ez irányú kutatások ugyan nem teljesen hiábavalóak, de valószinűleg nem hozhatnak belátható időn belüil gyümölcsöző eredményeket a japanológia és a hungarológia terén.

Befejezésül hadd említsem meg Bálint értesülését, miszerint a japán kormányzat 1873 táján azt a kérdést intézte a Magyar Tudományos Akadémiához, hogy igaz-e, hogy a japán nyelv a magyar nyelvvel rokon. ${ }^{36}$ Ez egy érdekes epizód lehet a japán-magyar nyelvhasonlítás történetében, de az e kérdésre vonatkozó írásos dokumentumra eddig sajnos még nem sikerült rábukkannom.

\footnotetext{
$131, \mathrm{~m} .12-213$

${ }^{34}$ Ono Susumu: Nihongo no seiritsu. Nihongo no sekai I. kötete. Tokió 1980. 77; 1 . még pl. a Nihongo no kigen. Sekai no gengogakusha ni yoru ronshü. Szerk. Mabuchi Kazuo. Tokió 1986. Angol cime: Origins of the Japanese language - An intemational collection of essays cimủ kötetben megjelent két angol nyelvủ írást Óno, ill. Pon. Kothandaraman tollából.

${ }^{35}$ L. Irén Hegedüs: Bibliographia Nostratica 1960-1990. (= Specimina Sibirica IV. Pẻcs 1992) cimủ kiadvảnyảnak rả vonatkozó irodalmả. L. még L. Kazảr ed.: Interdisciplinary international workshop .Providence of the Japanese language and the people with which an early stage of this language reached the Japanese island realm ". Hamburg $198 \overline{5}$.

ErdMúz. XI, 584-5; Tamulische Studien 7.
} 